\title{
New significant fossil insects from the Upper Carboniferous of Ningxia in northern China (Palaeodictyoptera, Archaeorthoptera)
}

\author{
$\mathrm{JAKUB}_{\mathrm{PROKOP}}{ }^{1}$ and DONG REN ${ }^{2}$
${ }^{1}$ Charles University in Prague, Faculty of Science, Department of Zoology, Viničná 7, CZ-128 44, Praha 2, Czech Republic; e-mail: jprokop@natur.cuni.cz
${ }^{2}$ College of Life Sciences, Capital Normal University, 105 Xisanhuanbeilu, Haidian District, Beijing 100037, P.R. China; e-mail: rendong@mail.cnu.edu.cn

Key words. Palaeodictyopteroida, Eugereonoidea, Breyerioidea, Archaeorthoptera, "Protorthoptera", fam. n., gen. n., sp. n., taxonomy, Late Paleozoic, Upper Carboniferous, Namurian, Ningxia, China

\begin{abstract}
New palaeodictyopterid Namuroningxia elegans sp. n. (Namuroningxiidae fam. n.) and archaeorthopterid Sinopteron huangheense gen. n., sp. n. (uncertain family assignment) are described from the Tupo Formation (Upper Carboniferous, Namurian, northern China, Ningxia Hui Autonomous Region). Both new taxa exhibit a unique structure of their wing venation pattern. The Namuroningxiidae fam. $n$. bears a mosaic of characters diagnostic of several "palaeopteran" families throughout Palaeodictyopteroida and Eupalaeoptera. This fact is highly interesting in reference to the Namurian age known for the occurrence of the first winged insects as well as the palaeogeographical position of the locality far from all sites in Laurussia. The preliminary study of entomofauna diversity exhibit frequent occurrence of archaeorthopterid wing fragments (e.g., Sinopteron huangheense) forming up to 40 percent of all insect specimens demonstrate high abundance of this group in the early Late Carboniferous ecosystems.
\end{abstract}

\section{INTRODUCTION}

The Namurian is the earliest stage of the Upper Carboniferous with sudden occurrence of diverse winged insects (Pterygota) (e.g., Brauckmann et al., 2003). As a consequence of the scarce insect fossil record and the paucity of rather fragmentary specimens in the Late Devonian and Early Carboniferous we cannot estimate the time of origin of the pterygote insect groups (Prokop et al., 2005; Engel \& Grimaldi, 2004). The Namurian insect deposits are currently known from few localities all located in the Euro-American region, such as the Upper Silesian Coal Basin in the Czech Republic and Poland, Hagen-Vorhalle, Ruhr area in Germany, Charleroi Coal Basin in Belgium, South Limburg coal-field in the Netherlands and Manning Canyon Shale in Utah (USA) (Brauckmann et al., 1996; Hennig, 1981; Rasnitsyn \& Quicke, 2002). Outside of this area a new insect fauna known as "Qilianshan entomofauna" has been recently discovered from the Namurian $\mathrm{C}$ of Qilianshan Mountains in northern China (Hong, 1998). This locality is the first Namurian site providing fossil insects from the Far East. Its distant palaeogeographical situation from the other Carboniferous insect localities and occurrence in low latitudes is rather significant for our understanding of insect evolution (Rasnitsyn \& Quicke, 2002) (see Fig. 1). In the first insect systematic studies based on these deposits, Peng et al. (2005) and Zhang et al. (2006) presented descriptions of a new family Sinonamuropteridae Peng, Hong \& Zhang, 2005 (all taxa erroneously attributed by the authors to Diaphanopterodea, bearing character of branched $\mathrm{CuA}$ typical for Grylloblattida sensu Storozhenko, 2002 after Béthoux, pers. comm.) and a new genus of dragonfly Shenzhousia Zhang \& Hong, 2006 (Protodonata: Meganeuridae).

Fossils known as "Qilianshan biota" including plants, insects, other invertebrates and vertebrates such as fish are preserved in layers of Tupo Formation in outcrops along Qilianshan Mountains located in the Ningxia, Gansu and Inner Mongolia regions (China). Fossil insects have been collected in layers of the Tupo Formation in Zhongwei County of southern Ningxia Hui Autonomous Region, representing the oldest entomofauna known from China so far (Hong, 1998). The paralic development of Tupo Formation is formed by alternated beds of terrestrial and marine facies dated to stage $\mathrm{C}_{2} \mathrm{t}$ (Bashkirian - Moscovian) as equivalent of European Namurian B-C (Peng et al., 2005). The palaeoecological analysis based on fish fossils indicates near shore palaeoenvironment with possible role of secondary transportation (Lu et al., 2002).

Taxa described herein are attributed to the Palaeodictyopteroida (Namuroningxiidae fam. n., Namuroningxia elegans gen. n., sp. n.) and Archaeorthoptera (Sinopteron huangheense gen. n., sp. n.), and both could be considered as suitable candidates to basal groups within Pterygota.

\section{MATERIAL AND METHODS}

The fossil specimens were observed under a stereomicroscope Olympus SZX-12 in dry state and under ethyl alcohol. The venation patterns were drawn directly using a stereomicroscope with a camera lucida and finally readjusted to the photograph scales using image-editing software (Adobe Photoshop). Photographs were made simultaneously using a digital camera Olympus 5050 by single sided cross-light exposure. 


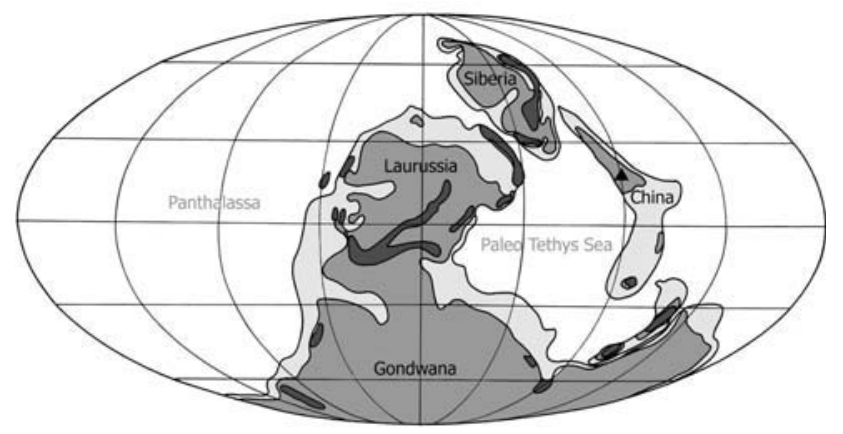

Fig. 1. Palaeogeographical world map of the Upper Carboniferous with approximate position of the locality in Zhongwei County, Ningxia Hui Autonomous Region (China) indicated by black triangle, after Scotese (2005, modified).

Type material referred to as "CNU" is housed at the Key Lab of Insect Evolution \& Environmental Changes, the College of Life Science, Capital Normal University, Beijing, China (CNU; Ren Dong, Curator).

We follow the wing venation nomenclature of Kukalová-Peck (1991) and Béthoux \& Nel (2002a) as elaborated for Archaeorthoptera. Systematics and divisions follow the concept of Palaeodictyopteroida sensu Bechly $(1996,2005)$ and Archaeorthoptera sensu Béthoux \& Nel (2002a, b).

\section{SYSTEMATICS}

Superorder Palaeodictyopteroida Bechly, 1996

Superfamily Eugereonoidea Sinitshenkova, 2002

Family Namuroningxiidae fam. $\mathbf{n}$.

Type genus. Namuroningxia gen. $\mathrm{n}$.

Diagnosis. Based on fore wing venation: wing elongated with the broadest part at about mid wing, wing generally covered with coarse irregular network of cross-veins and rather dense small cells (= archedictyon) in distal part; zigzagged intercalary veins present; posterior wing margin with long and dense setation; $\mathrm{CP}$ reaching anterior margin close to wing base; ScA reaching anterior margin about twice distance as $\mathrm{CP}$; $\mathrm{ScP}$ nearly straight, reaching anterior wing margin close to wing apex; RA and RP basally fused into R+ veinal stem, bifurcating at about $1 / 3$ wing length; simple RA basally diverged to ScP reaching anterior wing margin near apex; $\mathrm{RP}$ divided into five branches; stem of $\mathrm{M}$ adjacent to radial stem in basal part, $M$ divided into $M A$ and $M P$ about the same level as division RA and RP; MA simple; MA and RP connected by a short cross-vein (brace); MP basally divided dichotomously into two main branches, both secondarily forked reaching posterior wing margin together with five terminal branches; $\mathrm{CuA}$ simple, strongly diverging from $\mathrm{M}$ in basal part; short oblique cross-vein (brace) between $\mathrm{CuA}$ and $\mathrm{M}$; $\mathrm{CuP}$ bifurcated basally into two main branches near division $\mathrm{CuA}$ and $\mathrm{CuP}$; long anterior branch of $\mathrm{CuP}$ secondarily divided dichotomously ending on posterior wing margin with three branches, posterior branch of $\mathrm{CuP}$ deeply bifurcated; AA and AP basally fused forming anal area with five anal branches.

\section{Genus Namuroningxia gen. $\mathbf{n}$.}

Type species. Namuroningxia elegans $\mathrm{sp}$. $\mathrm{n}$. by present description.

Diagnosis. As for the family.

Etymology. Composite name after Namurian (stratigraphical stage) and Ningxia (Ningxia Hui Autonomous Region, name in northern China); feminine in gender.

\section{Namuroningxia elegans sp. $\mathbf{n}$.}

(Figs 2-3)

Diagnosis. By monotypy, that of the genus.

Description. Holotype specimen CNU-P-NX2006001. Wing large with the broadest part at about mid wing, membrane probably originally hyaline with pattern of dark coloration; wing generally covered with coarse irregular network of cross-veins and rather dense small cells in distal part of radial branches; zigzagged intercalary veins present; posterior wing margin distinctly bearing rather long and dense setation; vein axillary sclerites solid and well recognizable; short CP reaching anterior margin close to wing base about $4.4 \mathrm{~mm}$; prominent short convex ScA reaching anterior margin about twice the distance as $\mathrm{CP}$; concave $\mathrm{ScP}$ nearly straight, reaching anterior wing margin very distally, about $6 \mathrm{~mm}$ from wing apex; two rows of cells in basal part and numerous simple cross-veins in area between $\mathrm{C}$ and ScP; RA and $\mathrm{RP}$ basally fused into $\mathrm{R}+$ veinal stem, separating from each, at about $1 / 3$ wing length, $21.7 \mathrm{~mm}$ from wing base; simple RA orientated towards ScP probably reaching anterior wing margin near apex; RP nearly straight divided into five visible branches, all reaching apical area of wing; first fork of RP about $41 \mathrm{~mm}$ from wing base; RP area is covered with dense irregular network of small cells in distal part; stem of $\mathrm{M}$ adjacent to radial stem in basal part, $M$ divides into MA and MP about the same level as division RA and RP; MA simple, orientated towards RP in basal part, ending on posterior wing margin; MA and RP connected by short cross-vein, about 5 mm from division of MA and MP; MP basally divided dichotomously into two main branches about $28.9 \mathrm{~mm}$ from wing base, both secondarily forked reaching posterior wing margin together with five terminal branches; $\mathrm{CuA}$ and $\mathrm{CuP}$ fused basally into $\mathrm{Cu}$ veinal stem, diverging from each other at about $11.3 \mathrm{~mm}$ from wing base; $\mathrm{CuA}$ simple, orientated towards $\mathrm{M}$ in basal part, ending on posterior wing margin $44.5 \mathrm{~mm}$ from wing base; short prominent oblique cross-vein (brace) between $\mathrm{CuA}$ and $\mathrm{M}$ stem about $6.5 \mathrm{~mm}$ from division of $\mathrm{CuA}$ and $\mathrm{CuP}$; concave $\mathrm{CuP}$ bifurcated basally into two main branches near division $\mathrm{CuA}$ and $\mathrm{CuP}$; long anterior branch of CuP secondarily divided dichotomously ending on posterior wing margin with three branches, posterior branch of $\mathrm{CuP}$ deeply bifurcated; five anal veins preserved, forming anal area; the anal brace is formed by stiffened membrane in conjunction with basal portions of $\mathrm{AA}$; stem AA divided into two branches $\mathrm{AA}_{1-2}$ and $\mathrm{AA}_{3-4}$ about $6.1 \mathrm{~mm}$ from wing base and distinctly divided by prominent intercalary veins; AP is basally adjacent to AA ending with three terminal branches near wing base. 

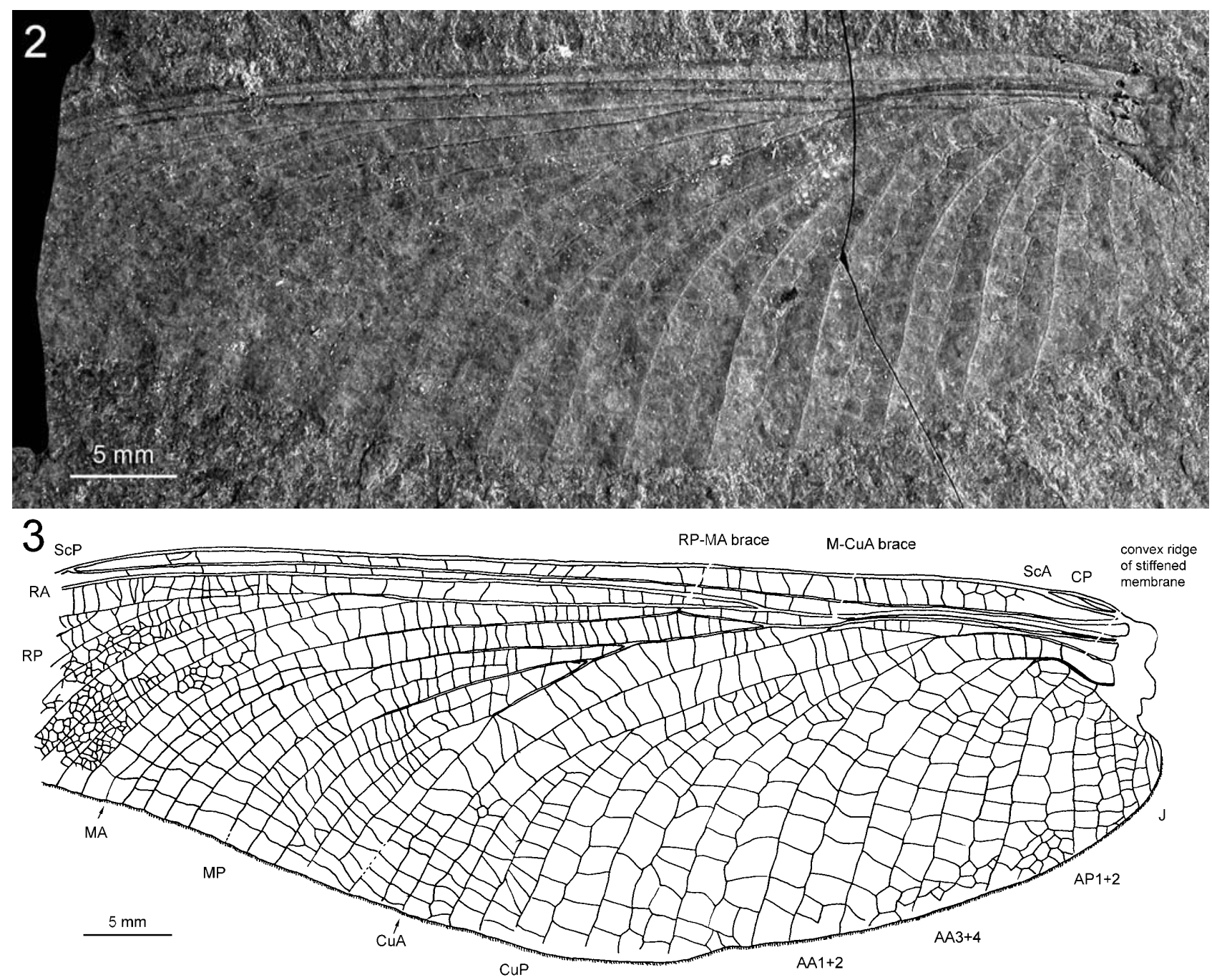

Figs 2-3. Namuroningxia elegans gen. n. et sp. n. 2 - holotype specimen No. CNU-P-NX2006001; 3 - fore wing venation.

Dimensions. Length of fragment about $62.5 \mathrm{~mm}$, probable total length about $67 \mathrm{~mm}$ (wingspan more than 135 $\mathrm{mm}$ ); wing width about $22.9 \mathrm{~mm}$.

Holotype. Specimen CNU-P-NX2006001, a nearly complete and well-preserved right fore wing, negative imprint, Capital Normal University coll., Beijing

Type locality. Xiaheyan Village of Zhongwei County, Ningxia Hui Autonomous Region, China.

Type strata. Upper Carboniferous, Namurian B-C, Tupo Formation.

Etymology. Named after the magnificent state of specimen preservation, elegans in Latin.

Discussion. The crucial problem of attribution of selected fossils to Palaeoptera Martynov, 1923 at superordinal level [extinct Palaeodictyopteroida Bechly, 1996 and Eupalaeoptera Bechly, 1996 (= Hydropalaeoptera sensu Kukalová-Peck)] is the presence of convergent characters in venation pattern of several members. For instance the Syntonopteridae Handlirsch, 1911, including Syntonoptera Handlirsch, 1911 and Lithoneura Carpenter, 1938, were first attributed to the Palaeodictyoptera (now in Palaeodictyopteroida) and later considered as Ephemeroptera (now in Eupalaeoptera) after the pres- ence of intercalary veins (Carpenter, 1992a; Edmuns \& Traver, 1954; Edmuns, 1972; Kukalová-Peck, 1985; Wootton, 1981; Willmann, 1999). However, the presence or absence of intercalary veins cannot be considered as a unique autapomorphy of the Eupalaeoptera, because of its occurrence in various Palaeodictyopteroida, e.g., a newly described genus of Calvertiellidae from the late Permian of France (Béthoux \& Nel, in press) and Protagrion audouini Brongniart, 1893 (Protagrionidae) from the Carboniferous of France (Béthoux \& Nel, 2003). The taxon described herein is another example bearing a mosaic of characters typical for several palaeopteran groups (see Table 1).

After detailed comparisons, the new wing is attributable within the superorder Palaeodictyopteroida sensu Bechly, 1996 (= Palaeodictyopteroidea sensu auct., Dictyoneuridea Handlirsch, 1906) bearing the symplesiomorphies of pterygote features in wing venation pattern such as pronounced $\mathrm{CP}$ - and $\mathrm{ScA}$ sensu Kukalová-Peck (1991), and the convex ridge formed by a stiffened membrane in conjunction with the basal portions of AA (homologous to anal veinal brace in Ephemeroptera + Odonatoptera), proposed as autapomorphic character of 
TABLE 1. Character matrix used to separate the families of Eugereonoidea, Breyerioidea (Palaeodictyoptera) and in addition Namurodiaphidae (Megasecoptera) and Syntonopteridae (Ephemeroptera).

\begin{tabular}{|c|c|c|c|c|c|c|c|c|c|c|c|c|c|c|c|}
\hline & 1 & 2 & 3 & 4 & 5 & 6 & 7 & 8 & 9 & 10 & 11 & 12 & 13 & 14 & 15 \\
\hline \multicolumn{16}{|l|}{ PALAEODICTYOPTERA } \\
\hline \multicolumn{16}{|l|}{ Eugereonoidea Sinitshenkova, 2002} \\
\hline Eugereonidae Handlirsch, 1906 & $0 / 1$ & 0 & 0 & 1 & 0 & 0 & 0 & 0 & 1 & $0 / 1$ & 0 & 0 & 0 & 1 & 1 \\
\hline Archaemegaptilidae Handlirsch, 1919 & 1 & 0 & 0 & 1 & 0 & 0 & 0 & 0 & 1 & 1 & 0 & 0 & 1 & 0 & 1 \\
\hline Graphiptilidae Handlirsch, 1906 & $?$ & 1 & 0 & 1 & $?$ & 0 & 1 & 0 & 2 & 1 & 0 & 1 & 1 & $? / 1$ & 1 \\
\hline Jongmansiidae Laurentiaux, 1950 & 1 & 0 & 0 & 1 & $?$ & 1 & $?$ & 1 & 0 & 1 & 0 & 0 & 1 & 0 & 1 \\
\hline Lithomanteidae Handlirsch, 1906 & 0 & 0 & 0 & 1 & $?$ & 1 & 0 & 0 & 1 & 0 & 0 & 0 & $0 / 1$ & 0 & 1 \\
\hline Lycocercidae Handlirsch, 1906 & 1 & $0 / 1$ & 0 & 1 & 1 & 0 & 1 & 0 & 1 & 1 & 0 & 0 & $0 / 1$ & 0 & 1 \\
\hline Megaptilidae Handlirsch, 1906 & $?$ & $0 / 1$ & 0 & 1 & $?$ & 0 & $?$ & 0 & $?$ & $?$ & 0 & 0 & $?$ & $? / 1$ & 1 \\
\hline Polycreagridae Handlirsch, 1906 & $? / 1$ & 1 & 2 & 1 & $?$ & 0 & 1 & 0 & 1 & 1 & 0 & 0 & 1 & 0 & 1 \\
\hline Protagriidae Handlirsch, 1906 & 1 & 0 & 2 & 0 & 0 & 1 & 1 & 0 & 2 & 0 & 0 & 0 & 1 & 0 & 1 \\
\hline Synarmogidae Handlirsch, 1910 & 0 & 1 & $0 / 1$ & 1 & 1 & 1 & 1 & 0 & 1 & $0 / 1$ & 0 & 1 & $0 / 1$ & 1 & 1 \\
\hline Tchirkovaeidae Sinitshenkova, 1979 & 1 & 0 & 2 & 1 & $?$ & 1 & 0 & 0 & 1 & 1 & 0 & 1 & 1 & 1 & 0 \\
\hline Namuroningxiidae fam. $\mathrm{n}$. & 1 & 0 & 2 & 0 & 0 & 0 & 0 & 0 & 0 & 0 & 0 & 0 & 0 & 0 & 0 \\
\hline \multicolumn{16}{|l|}{ Breyerioidea Handlirsch, 1904} \\
\hline Breyeriidae Handlirsch, 1906 & 0 & 0 & 1 & 1 & 0 & 1 & 0 & 0 & 0 & 1 & 0 & $0 / 1$ & $0 / 1$ & 1 & 0 \\
\hline Cryptoveniidae Bolton, 1912 & 1 & 1 & 1 & 1 & ? & 0 & $?$ & 0 & $?$ & $?$ & 1 & 1 & $?$ & 1 & 1 \\
\hline Stobbsiidae Handlirsch, 1908 & $?$ & 1 & 2 & 1 & $?$ & 1 & $?$ & 0 & 0 & $0 / 1$ & 0 & 1 & $? / 0$ & 1 & 1 \\
\hline \multicolumn{16}{|l|}{ MEGASECOPTERA } \\
\hline Namurodiaphidae Kukalová-Peck \& Brauckmann, 1990 & 1 & 0 & 1 & 1 & ? & 1 & 0 & 0 & 0 & 0 & 0 & 0 & 0 & 1 & 1 \\
\hline \multicolumn{16}{|l|}{ EPHEMEROPTERA } \\
\hline Syntonopteridae Handlirsch, 1911 & 1 & 0 & 1 & 0 & $?$ & 0 & 0 & 0 & 0 & 0 & 1 & 1 & 0 & 1 & 1 \\
\hline
\end{tabular}

Palaeoptera by Kukalová-Peck (1997). The current state of our knowledge on higher systematics and division of Palaeodictyopteroida is rather incomplete and partly confusing as was noticed by several authors (e.g., Carpenter, 1962, 1992b; Sinitshenkova, 1980). The systematic position of several families, such as Eubleptidae, Namurodiaphidae and many others, remains uncertain (e.g., Riek, 1976; Kukalová-Peck \& Brackmann, 1990, Sinitshenkova, 2002). Moreover, there is no real phylogenetic analysis of this group that we can simply follow. We follow the systems proposed by Riek (1976) and Sinitshenkova (2002) with additional comments based on recently published works.

Following the key of Riek (1976: 230), the wing venation pattern of this fossil is attributable to the group "Eupalaeodictyoptera", with the main characters of the super-family Eugereonoidea Handlirsch, 1906 (= Dictyoptiloidea sensu Riek, 1976) such as: (1) veins $\mathrm{CuA}$ and MA simple or with short terminal twigging; (2) separation of ScP from R extending almost to wing apex; (3) archedictyon reduced or open in form, veins $\mathrm{CuP}$ and MP branched. Carpenter (1964) synonymized Dictyoptilidae Riek, 1976 with Eugereonidae and the act has not been challenged yet. This is supported by Sinitshenkova (2002) who recently restored the taxon Eugereonoidea Handlirsch, 1906 adding another character in the diagnosis "wing length 2.5 times width" in her phylogenetic system of the Dictyoneurina (= Palaeodictyopteroida sensu Bechly, 1996). The Eugereonoidea includes eleven families (Eugereonoidae, Archaemegaptilidae, Graphip- tilidae, Jongmansiidae, Lithomanteidae, Lycocercidae, Megaptilidae, Polycreagridae, Protagriidae, Synamorgidae and Tchirkovaeidae). Despite of the fact that this last system is not based on the cladistic method, we follow Sinishenkova's classification in this paper.

We tentatively include the Namuroningxiidae fam. $n$. close to the Tchirkovaeidae (Eugereonoidea) from the Upper Carboniferous of Tunguska and Kuznetsk basins (Sinitshenkova, 1981), because they share a rather coarse pattern of cross-veins and a long setation of the posterior wing margin. It differs mainly by fewer branches of MP, $\mathrm{CuP}$, and veins MA \& RP and $\mathrm{CuA} \& \mathrm{M}$ not shortly braced.

Within the Eugereonoidea, Namuroningxiidae fam. n. is mainly characterized by the presence of zigzagged intercalary veins, a rather coarse network of reticulate venation dense in apical part, ScP ending near wing apex, division of MA \& MP on the same level as RA \& RP, MA \& RP, and CuA \& M shortly braced (see Table 1).

Besides Eugereonoidea we found strong similarity to other families, especially to Breyeriidae (Breyerioidea), sharing a similar structure of a rather coarse network of reticulate venation, stems of $\mathrm{R}$ and $\mathrm{M}$ basally in contact, and prominent dense long setation of the posterior wing margin as typical character for this family and Tchirkovaeidae throughout all Palaeodictyoptera (= Dictyoneurida Handlirsch, 1906) (Kukalová, 1969: 464, Sinitshenkova, 1981: 123). The Breyeriidae differs mainly from Namuroningxiidae by the $\mathrm{ScP}$ terminating 

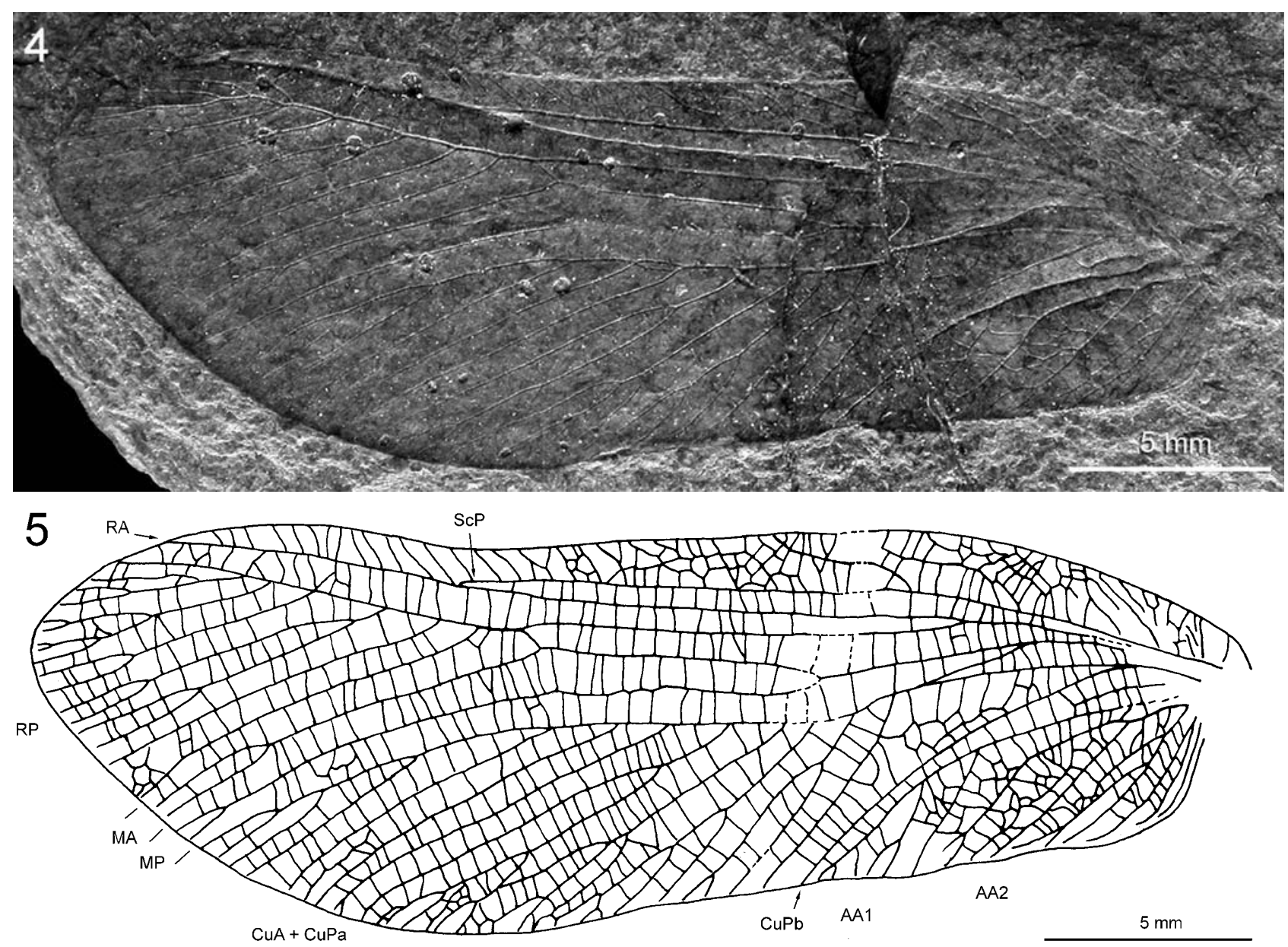

Figs 4-5. Sinopteron huangheense gen. n. et sp. n. 4 - holotype specimen No. CNU-A-NX2006001; 5 - fore wing venation.

about mid wing, $\mathrm{CuA}$ widely separated from the stem of $\mathrm{M}$ and a much less developed $\mathrm{CuP}$.

Therefore we propose a new family for this fossil, probably related to Tchirkovaeidae (Eugereonoidea), but also sharing venation characters particularly to Breyeriidae (Breyerioidea).

\section{Super-order Archaeorthoptera Béthoux \& Nel, 2002 Genus Sinopteron gen. n.}

Type species. Sinopteron huangheense sp. n. by present description.

Diagnosis. Based on fore-wing venation: $\mathrm{ScP}$ ending on RA at distal third of wing; area between ScP and anterior wing margin rather broad and reticulate (anterior pectination not expressed) with sigmoidal cross-veins; division RA and RP in basal fourth of wing; RA reaching anterior wing margin near apex; RP basally close and parallel to RA, slightly diverging near level of short connection with MA; RP pectinate with six main posterior and two anterior branches covering the whole wing apex; stem $\mathrm{M}+\mathrm{CuA}$ rather long; stem $\mathrm{M}$ diverging distally of division RA and RP; MA deeply bifurcated, anterior branch partly connected with RP; distinctly concave MP terminally twigged; prominent free convex $\mathrm{CuA}$ rather long; area between $\mathrm{CuA}+\mathrm{CuPa}$ and $\mathrm{CuPb}$ broad with a network of cells; $\mathrm{CuA}+\mathrm{CuPa}$ pectinate with ten posterior branches bearing two thirds of whole posterior wing margin; $\mathrm{CuPb}$ simple; area between $\mathrm{CuPb}$ and $\mathrm{AA} 1$ narrow; AA1 ending with two main branches; AA2 pectinate, anal area reticulate.

Etymology. Composite name after Latin words: Sinae (China) and pteron (wing); neutrum in gender.

\section{Sinopteron huangheense sp. $\mathbf{n}$.}

(Figs 4-7)

Diagnosis. By monotypy, that of the genus.

Description. Holotype specimen CNU-A-NX2006001. Moderate wing with the broadest part in distal third, membrane probably originally with dark coloration; slightly curved ScP ending on RA in distal third of wing, about $19.2 \mathrm{~mm}$ from wing base; branches ScP strongly reticulated, anterior pectination not expressed; area between $\mathrm{ScP}$ and anterior wing margin rather broad with four rows of cells and numerous sigmoidal cross-veins; basally bowed R stem bifurcated about $7.3 \mathrm{~mm}$ from wing base; convex simple RA reaching anterior wing margin near apex without distinct anterior terminal branches; RP basally close and parallel to RA, slightly diverging near the level of the short connection with MA; RP with six main posterior and two short anterior branches covering the whole wing apex; posterior branches commonly terminally twigged; area between RA and RP with numerous 

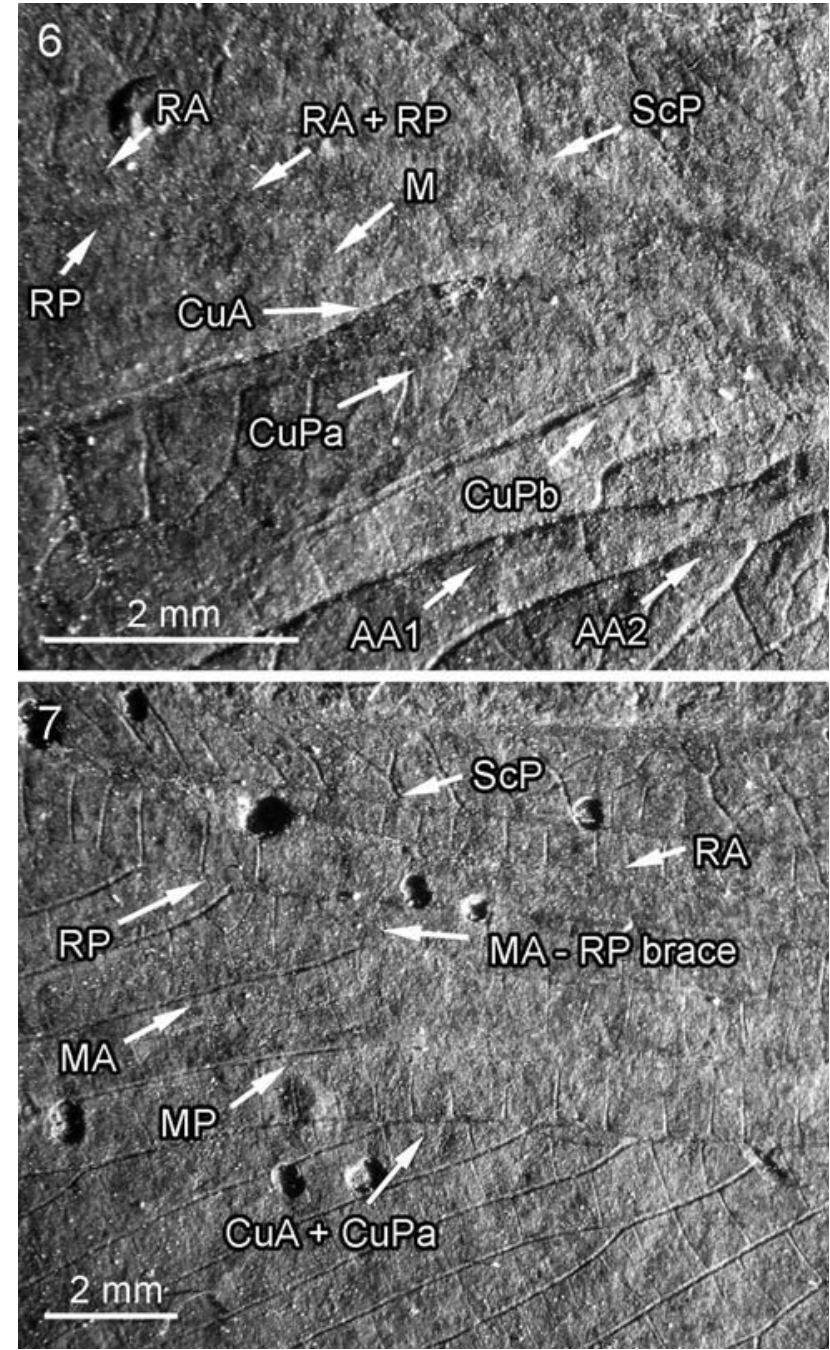

Figs 6-7. Sinopteron huangheense gen. n. et sp. n. (holotype specimen No. CNU-A-NX2006001). 6 - detail of the wing base; 7 - detail of the antero-medial part.

parallel cross-veins; convex stem $\mathrm{M}+\mathrm{CuA}$ about $5.3 \mathrm{~mm}$ long; neutral stem of $\mathrm{M}$ diverging distally of division RA and $\mathrm{RP}$ about $4.7 \mathrm{~mm}$ from division of $\mathrm{M}$ and $\mathrm{CuA}$; slightly convex or neutral MA deeply bifurcated, anterior branch partly connected with RP for about $7.5 \mathrm{~mm}$, posterior branch terminally twigged; concave MP shortly terminally twigged; prominent free convex $\mathrm{CuA}$ slightly diverging to posterior wing margin behind the division of $\mathrm{M}$ and $\mathrm{CuA}$ and subsequently fusing with $\mathrm{CuPa}$; free $\mathrm{CuA} 2.6 \mathrm{~mm}$ long; area between $\mathrm{CuA}+\mathrm{CuPa}$ and $\mathrm{CuPb}$ largely broadened, with a network of cells; convex $\mathrm{CuA}+$ $\mathrm{CuPa}$ with ten branches bearing two thirds of whole posterior wing margin; simple concave $\mathrm{CuPb}$ emerging from stem of CuP about $3.4 \mathrm{~mm}$ from wing base; area between $\mathrm{CuPb}$ and $1 \mathrm{~A}$ narrow; convex $1 \mathrm{~A}$ ending with two main branches; 2A pectinate with five main posterior branches, anal area distinctly reticulate.

Dimensions. Length of fragment $29 \mathrm{~mm}$, probable total length about $32 \mathrm{~mm}$ (wingspan about $70 \mathrm{~mm}$ ); wing width $9 \mathrm{~mm}$ (opposite of ending ScP to RA).
Holotype. CNU-A-NX2006001, nearly complete and wellpreserved right fore wing with very basal part missing, Capitol Normal University coll., Beijing; Paratype CNU-ANX2006002-1, CNU-A-NX2006002-2 both pairs of folded wings partly preserved, fragments of thorax and prothoracic legs, Capitol Normal University coll., Beijing. "Explicit exclusion".

Type locality. Xiaheyan Village of Zhongwei County, Ningxia Hui Autonomous Region, China.

Type strata. Upper Carboniferous, Namurian B-C, Tupo Formation.

Etymology. Named after the Huanghe River located close to the type locality.

Discussion. Our current state of knowledge on the higher systematics and division of "Protorthoptera" is rather complicated and partly confusing (Carpenter, 1992a). There is no real phylogenetic analysis of this group that we can simply follow. However, the present wing is clearly attributable to the supra-ordinal clade Archaeorthoptera. In this case we have followed the phylogeny proposed by Béthoux (2005b) and Béthoux \& Nel (2002b) who designated Archaeorthoptera, a clade that includes the group Panorthoptera [Orthoptera + Caloneurodea $+($ Titanoptera + Geraridae $)]$ and part of unassigned taxa of "Protorthoptera". Further attribution excludes the whole clade Panorthoptera as Sinopteron has a simple $\mathrm{CuPa}$, and was directly compared with other unassigned taxa based on assessments provided by Carpenter (1992) and other recent works (e.g., Béthoux, 2005a, b; Béthoux $\&$ Nel, 2005) with additional comments. We avoid any familial attribution until a phylogenetic analysis of the whole Archaeorthoptera will resolve the possible relationships among the described species.

The present wing is clearly attributable to the supraordinal clade Archaeorthoptera Béthoux \& Nel, 2002b after the following combination of characters: convex $\mathrm{CuA}$ emerging from convex $\mathrm{M}+\mathrm{CuA}$ near the basal sixth of the wing, distally fused with the anterior branch of $\mathrm{CuP}(\mathrm{CuPa})$ (autapomorphy); $\mathrm{ScP}$ anteriorly reticulate; origin of RP at basal third of wing length; $\mathrm{M}$ divided into a neutral MA and a concave MP; MA divided into two branches, MA1 and MA2; partial fusion between MA1 and RP present; $\mathrm{CuA}$ fused with $\mathrm{M}$ at the very base of the wing; $\mathrm{M}$ neutral after its separation from $\mathrm{CuA}$; convex $\mathrm{CuA}+\mathrm{CuPa}$ with ten branches; CuP divided into two branches, $\mathrm{CuPa}$ and $\mathrm{CuPb}$ (autapomorphy); area between $(\mathrm{CuPa} / \mathrm{CuA}+\mathrm{CuPa})$ and $\mathrm{CuPb}$ very broad, with a network of cells; simple concave $\mathrm{CuPb}$; $\mathrm{AA} 1$ convex, emerging at the very wing base; network of cells and cross-veins between main veins. After the work of Kukalová-Peck \& Lawrence (2004) this wing can be placed within modern Orthoneoptera sensu Haas \& Kukalová-Peck (2001) by the combination of the following characters: stem of M formed (MA and MP fused, apomorphy) and MA shortly fused with RP (apomorphy), stem of $\mathrm{Cu}$ absent, $\mathrm{CuP}$ forked (two plesiomorphies); $\mathrm{CuP}$ $1+2$ fused to $\mathrm{CuA}$ (apomorphy); $\mathrm{CuA}$ fused at wing base to $\mathrm{M}$ and separating again soon (apomorphy).

Further placement of Sinopteron gen. n. is tentative and based on character sharing that could be indicative of 
possible relationships of the closest taxa. Major characters of the wing venation pattern suggest some similarities to genera of the following families: Stenoneuridae Handlirsch, 1906 and Ischnoneuridae Handlirsch, 1906 (Carpenter, 1992a). However, some genera like Eoblatta Handlirsch, 1906 and Ctenoptilus Lameere, 1917 were recently re-described and their familial attributions were doubted by Béthoux \& Nel (2005: 308). Sinopteron also shares with Tococladidae the anterior branch MA anastomosed with RP and the area between $(\mathrm{CuPa} / \mathrm{CuA}+\mathrm{CuPa})$ and $\mathrm{CuPb}$ very broad (Carpenter, 1966), but it mainly differs in its much reduced $\mathrm{CuA}+\mathrm{CuPa}$. In any case we prefer to compare Sinopteron directly with other genera across the known families.

Eoblatta Handlirsch, 1906 and Ctenoptilus Lameere, 1917, both have a general appearance similar to Sinopteron but differing mainly by shorter $\mathrm{CuA}$ free, MA simple or terminally twigged and not connected with RP. Sinopteron especially resembles Ctenoptilus described from Commentry Basin, Allier in France (Stephanian $\mathrm{B}-\mathrm{C})$ by the structure of the RP, presence of anterior branches of $\mathrm{RP}$ and a very large area $\mathrm{CuA}+\mathrm{CuPa}$ (Béthoux \& Nel, 2005: 292-297, Figs 7-11).

Anegertus Handlirsch, 1911 shares with Sinopteron numerous branches of ScP, the basal division of RA and $\mathrm{RP}$ and a dense network of cross-veins. This genus differs from Sinopteron by its more distal branching of $\mathrm{M}$ not regularly curved MA (Béthoux, 2005b).

Nectoptilus Béthoux, 2005 described from Mazon Creek, Illinois, USA (Westphalian D) and Ctenoptilus Lameere, 1917 share with Sinopteron a well developed $\mathrm{CuA}+\mathrm{CuPa}$ area, but differ mainly in a more distal position of the bifurcation of MA and MP and a less developed RP area (Béthoux, 2005b).

Lobeatta Béthoux, 2005 described from Mazon Creek, Illinois, USA (Westphalian D) differs mainly from Sinopteron in a considerably narrower $\mathrm{CuA}+\mathrm{CuPa}$ area and a loose cross-vein network (Béthoux, 2005b).

Sinopteron differs from all Cnemidolestodea (including Bouleites) after its free MP (fused with $\mathrm{CuA}+\mathrm{CuPa}$ in Cnemidolestodea). It shares with "lobeattid" taxa (see Béthoux, 2005b) a very basal branching of R into RA and RP. It differs from all known "lobeattid" taxa after its organization of $\mathrm{CuA}+\mathrm{CuPa}$ (in Eoblatta, Ctenoptilus, Anegertus, Nectoptilus, and Lobeatta, the first posterior branch of $\mathrm{CuA}+\mathrm{CuPa}$ has many more branches than further posterior branches of $\mathrm{CuA}+\mathrm{CuPa}$, unlike in Sinopteron) and the occurrence of a connection between RP and MA1 [but Ctenoptilus Béthoux \& Nel, 2005: Fig. 9; this character is not always stable in basal Archaeoptera (see Béthoux \& Nel, 2005: Figs 9, 15)].

Furthermore, Sinopteron is significantly smaller than any other lobeattid insects, all having nearly twice as broad forewings.

Despite of difficulties with familial attribution of Sinopteron within Archaeorthoptera, we certainly present a new combination of characters sufficient for a generic separation.

\section{CONCLUSIONS}

The material from Ningxia represents an extraordinary source of fossil insects from the Namurian of northern China. Both newly described taxa exhibit extraordinary antiquity by the combination of numerous plesiomorphic character states in the wing venation pattern.

Namuroningxiidae fam. $\mathrm{n}$. is established for Namuroningxia gen. n. (type genus) that is based on Namuroningxia elegans sp. $\mathrm{n}$. (type species). Namuroningxiidae bears a mosaic of characters diagnostic of several palaeopteran families throughout Palaeodictyopteroida (Palaeodictyoptera, Megasecoptera) and Eupalaeoptera (Ephemeroptera). It is probably closely related to the Tchirkovaeidae (Eugereonoidea), but it also shares several characters with Breyeriidae (Breyerioidea), mainly those of coarse irregular network and long setation along the posterior wing margin. Nevertheless, the fossil shares particular characters with other groups, e.g., the convergence of zigzagged intercalary veins such as in Syntonopteridae (Ephemeroptera).

Sinopteron gen. n. is established for Sinopteron huangheense sp. n. (type species) that also exhibits a mosaic of characters pointing to the non-natural assessment of certain families within Archaeorthoptera as previously proposed by Béthoux \& Nel (2005). However, this taxon represents an evolutionary success and its pattern of wing venation persisted with slight modifications from Namurian to Stephanian B-C for Anegertus, Ctenoptilus, Eoblatta, Lobeatta and Nectoptilus. The evidence for success of archaeorthopterid insects is supported by the frequent occurrence of this group, forming up to 40 percent of all insect fauna, indicating a high abundance in Late Carboniferous ecosystems.

In conclusion it is highly interesting to point out Namurian age of the fossils when the first undisputed evidence of winged insects recorded as well as rather remote palaeogeographical location far from all other known localities in Laurussia and Siberia. Moreover, Sinopteron is likely a close relative of taxa known from North America and Western Europe. However, it differs markedly in size being half the size of all related Euroamerican taxa. This contrast presents a possible link between tropical and temperate faunas in the Late Carboniferous.

ACKNOWLEDGEMENTS. We are grateful to A. Nel (MNHN, Paris) for his constructive comments on the manuscript. We thank to J. Kukalová-Peck (Carleton University), G. Bechly (Staatliches Museum für Naturkunde, Stuttgart), O. Béthoux (Yale University) and P. Štys (Charles University) for their revision and suggestions on an earlier version of the manuscript. The first author acknowledges the research support from the Grant Agency of Academy of the Czech Republic No. KJB301110701, and Ministry of Schools MSM 0021620828. The second author D. Ren was supported by grants from the National Nature Science Foundation of China (Nos 30370184, 30430100), the Scientific Research Key Program (KZ200410028013) and the RCQJ Project of Beijing Municipal Commission of Education. This is contribution to IGCP \#469 (Variscan Terrestrial Biotas and Palaeoenvironments). 


\section{REFERENCES}

BECHLY G. 1996: Morphologische Untersuchungen am Flügelgeäder der rezenten Libellen und deren Stammgruppenvertreter (Insecta; Pterygota; Odonata) unter besonderer Berücksichtigung der Phylogenetischen Systematik und des Grundplanes der *Odonata. Petalura (Spec. Vol.) 2: 1-402.

Bechly G. 2005: Phylogenetic Systematics of Odonata. http:\\ www.naturkundemuseum-bw.de/stuttgart/projekte/bernstein/o donata/index.htm

BÉTHoux O. 2005a: Cnemidolestodea (Insecta): an ancient order reinstated. J. Syst. Palaeont. 3: 403-408.

BÉTHOUX O. 2005b: Reassigned and new basal Archaeorthoptera from the Upper Carboniferous of Mazon Creek (IL, USA). $J$. Orthoptera Res. 14: 121-126.

BÉTHoux O. \& Nel A. 2002a: Venation pattern of Orthoptera. $J$. Orthoptera Res. 10[2001]: 195-198.

BÉTHOuX O. \& Nel A. 2002b: Venation pattern and revision of Orthoptera sensu nov. and sister groups. Phylogeny of Palaeozoic and Mesozoic Orthoptera sensu nov. Zootaxa 96: 1-88.

Béthoux O. \& Nel A. 2003: Révision de Protagrion audouini Brongniart, 1893, du Carbonifère supérieur (Palaeoptera). Bull. Soc. Entomol. Fr. 108: 237-244.

BÉthoux O. \& Nel A. 2005: Some Palaeozoic "Protorthoptera" are "ancestral" orthopteroids: major wing braces as clues to a new split among the "Protorthoptera". J. Syst. Palaeont. 2(4): $1-25$.

Béthoux O., Nel A., Schneider J.W. \& Gand G. in press: Lodetiella magnifica nov. gen. and nov. sp. (Insecta: Palaeodictyoptera; Permian), an extreme case in wing morphology of palaeopterous insects. Geobios

Brauckmann C., Brauckmann B. \& Gröning E. 1996: The stratigraphical position of the oldest known Pterygota (Insecta, Carboniferous, Namurian). Ann. Soc. Geol. Belgique 117: $47-56$.

Brauckmann C., Schöllmann L. \& Sippel W. 2003: Die fossilen Insekten, Spinnentiere und Eurypteriden von Hagen-Vorhalle. Geol. Paläontol. Westf. Westfäl. Mus. Naturk. 59: 1-89.

CARPenter F.M. 1962: A Permian Megasecoptera from Texas. Psyche 69: 37-41.

Carpenter F.M. 1964: Studies on Carboniferous insects from Commentry, France. Part VI. The genus Dictyoptilus (Palaeodictyoptera). Psyche 71: 104-116.

Carpenter F.M. 1966: The Lower Permian insects of Kansas. Part II. The orders Protorthoptera and Orthoptera. Psyche 73: 46-87.

Carpenter F.M. 1992a: Superclass Hexapoda. In: Moore R.C. \& Kaesler R.L. (eds): Treatise on Invertebrate Paleontology. Arthropoda 4, Vol. 3/4. The Geological Society of America and the University of Kansas, Boulder, Colorado, $655 \mathrm{pp}$.

CARPENTER F.M. 1992b: Studies of North American Carboniferous insects. Part 9. A new species of Eubleptidae from Mazon Creek (Palaeodictyoptera). Psyche 99: 147-152.

EDMUNDS G.F. JR. 1972: Biogeography and evolution of Ephemeroptera. Annu. Rev. Entomol. 17: 21-42.

Edmunds G.F. JR. \& Travers J.R. 1954: An outline of the reclassification of the Ephemeroptera. Proc. Entomol. Soc. Wash. 56: 236-240.

Engel M.S. \& Grimaldi D.A. 2004: New light shed on the oldest insect. Nature 427: 627-630.

HaAs F. \& Kukalová-Peck J. 2001: Dermaptera hindwing structure and folding: new evidence for familial, ordinal and superordinal relationships within Neoptera (Insecta). Eur. J. Entomol. 98: 445-509.

Hennig W. 1981: Insect Phylogeny. J. Wiley, Chichester, NY, $514 \mathrm{pp}$.
HoNG Y.-C. 1998: Establishment of fossil entomofaunas and their evolutionary succession in North China. Entomol. Sin. 5: 283-300.

KuKaloví J. 1969: Revisional study of the order Palaeodictyoptera in the Upper Carboniferous shales of Commentry, France. Part 2. Psyche 76: 439-486.

KuKALOVÁ-PeCK J. 1985: Ephemeroid wing venation based upon new gigantic Carboniferous mayflies and basis morphological phylogeny and metamorphosis of pterygopte insects (Insecta, Ephemerida). Can. J. Zool. 63: 933-955.

Kukalová-Peck J. 1991: Chapter 6. Fossil history and the evolution of hexapod structures. In Naumann I.D. (ed.): The Insects of Australia, a Textbook for Students and Research Workers 1. 2nd ed. Melbourne University Press, Melbourne, pp. 141-179.

KukalovÁ-Peck J. 1997: Chapter 19. Arthropod phylogeny and "basal" mophological structures. In Fortey R.A. \& Thomas R.H. (eds): Arthropod Relationships. Sys. Assoc. Spec. Vol. 55. Chapman \& Hall, London, pp. 249-268.

Kukalová-Peck \& Brauckmann 1990: Wing folding in pterygote insects, and the oldest Diaphanopterodea from the early late Carboniferous of West Germany. Can. J. Zool. 68: 1104-1111.

KukalovÁ-Peck J. \& Lawrence J.F. 2004: Relationships among coleopteran suborders and major endoneopteran lineages: Evidence from hind wing characters. Eur. J. Entomol. 101: 95-144.

Lu L., FAng X. JI S. \& PANG Q. 2002: A contribution to the knowledge of the Namurian in Ningxia. Acta Geosci. Sin. 23: 165-168.

Peng D., Hong Y. \& Zhang Z. 2005: Namurian insects (Diaphanopterodea) from Qilianshan Mountains, China. Geol. Bull. China 24: 219-234.

Prokop J., Nel A. \& Hoch I. 2005: Discovery of the oldest known Pterygota in the Lower Carboniferous of the Upper Silesian Basin in the Czech Republic (Insecta: Archaeorthoptera). Geobios 38: 383-387.

RASNITSYN A.P. \& QUicke D.L.J. (eds) 2002: History of Insects. Kluwer Academic Publishers, Dordrecht, Boston, London, xi +517 pp.

RIEK E.F. 1976: Neosecoptera, a new insect suborder based on specimen discovered in the Late Carboniferous of Tasmania. Alcheringa 1: 227-234.

Sinitshenkova N.D. 1980: [The order Dictyoneurida. The order Mischopterida. The order Permothemistida.] In Rohdendorf B.B. \& Rasnitsyn A.P. (eds): [Historical Development of the Class Insecta.] Trud. Paleont. Inst. Akad. Nauk SSSR 175: 44-49 [in Russian].

Sinitshenkova N.D. 1981: A new species of the Tchirkovaeidae (Dictyoneurida) from the Upper Carboniferous of the Tunguska basin. Paleont. J. 15: 144-145.

Sinitshenkova N.D. 2002: Chapter 2.2.1.2.3. Superorder Dictyoneuridea Handlirsch, 1906 (= Palaeodictyopteroidea). In Rasnitsyn A.P. \& Quicke D.L.J. (eds): History of Insects. Kluwer Academic Publishers, Dordrecht, Boston, London, pp. 115-124.

Storozhenko S.Y. 2002: Chapter 2.2.2.2.1. Order Grylloblattida Walker, 1914 (= Notoptera Crampton, 1915, = Grylloblattodea Brues et Melander, 1932, +Protorthoptera Handlirsch, 1906, = Paraplecoptera Martynov, 1925, +Protoperlaria Tillyard, 1928). In Rasnitsyn A.P. \& Quicke D.L.J. (eds): History of Insects. Kluwer Academic Publishers, Dordrecht, Boston, London, pp. 278-284.

Willmann R. 1999: The Upper Carboniferous Lithoneura lameerei (Insecta, Ephemeroptera?). Paläontol. Z. 73: 289-302. 
Wootton R.J. 1981: Palaeozoic insects. Annu. Rev. Entomol. 26: $319-344$.

Wootton R.J. \& KuKalovÁ-Peck J. 2000: Flight adaptations in Palaeozoic Palaeoptera (Insecta). Biol. Rev. 75: 129-167.

Zhang Z., Hong Y., Lu L., FAng X. \& JiN Y. 2006: Shenzhousia qilianshanensis gen. et sp. nov. (Protodonata, Meganeuridae), a giant dragonfly from the Upper Carboniferous of China. Progr. Nat. Sci. 16: 328-330.

\section{APPENDIX}

List of coded characters used to separate the families of Eugereonoidea sensu Sinitshenkova, 2002 (= Dictyoptiloidea sensu Riek, 1976), Breyerioidea Handlirsch, 1904 and other families based on wing venation pattern, see Table 1:

1. Wing shape: anterior wing margin strongly convexly curved [0]; anterior wing margin nearly straight [1].

2. Wing shape: wing considerably elongated, broadest in the mid wing [0]; wing not elongated or broadest basally [1].

3. "Archedictyon": (= reticulate venation after Wootton \& Kukalová-Peck, 2000): present [0]; absent [1]; uncertain or coarse and partially present [2].

4. Zigzzaged intercalary veins: present [0]; absent [1].

5. Precostal area: present [0]; absent [1].
6. ScP: ending on wing apex or very close [0]; ending well before wing apex [1].

7. Stem R and M: basally shortly connected or coalesced [0]; basally well separated [1].

8. RP: with four or more branches [0]; with less than four branches [1].

9. Division of MA \& MP on the same level as RA \& RP [0]; MA \& MP slightly distal position as RA \& RP [1]; MA \& MP far from division RA \& RP [2].

10. MA: shortly connected (braced) with RP [0]; not braced with RP [1].

11. MA and $\mathrm{CuA}$ : free or terminally twigged [0]; with prominent branching [1].

12. MP: deeply bifurcated ending with four or more branches [0]; not deeply bifurcated ending with less than four branches [1].

13. CuA: shortly connected (braced) with $\mathrm{M}[0]$; not braced with $\mathrm{M}[1]$.

14. CuP: with four or more branches [0]; with less than four branches [1].

15. Posterior wing margin: with dense long setation [0]; without long setation [1]

Received May 19, 2006; revised and accepted February 7, 2007 